HANNA ŻURAW

ZakŁad Pedagogiki Specjalnej i Logopedi

Pedagogium WsNs

E-MAIL:H.ZURAW@ONET.EU

\title{
EWOLUCJA PODEJŚCIA DO NIEPEŁNOSPRAWNOŚCI W KULTURZE ZACHODU -PERSPEKTYWA ANTROPOLOGII
}

\section{Uwarunkowania globalnego podejścia do niepełnosprawności w kulturze Zachodu}

W ustosunkowaniu się społeczeństw wobec niepełnosprawności na przestrzeni dziejów dadzą się wyodrębnić dwie główne epoki. Pierwsza obejmowała erę preindustrialną i industrialną, drugą stanowią czasy postindustrialne. W każdej z nich działały w specyficzny sposób czynniki kształtujące ustosunkowania społeczeństw do niepełnosprawności. Były to czynniki uprzednie wobec systemu społecznego, cechy porządku aksjonormatywnego: stosunek do ciała, koncepcja i ideał człowieczeństwa, charakter produkcji, lokalizacja władzy, poziom rozwoju nauki i technologii, rozmiary medykalizacji, segregacji i etykietyzacji, poziom zaangażowania państwa w rozwiązywanie problemów ludzi słabych, wyjaśnienia przyczyn odmienności, powszechność szkolnych umiejętności, poczucie zagrożenia versus bezpieczeństwa, dostęp do informacji, cechy jednostki.

Te czynniki kształtowały elementy składowe ustosunkowań społeczeństwa wobec niepełnosprawności, a w tym przyzwolenie na życie odmieńców, zgodę ich na udział w głównym nurcie życia społecznego z pełnieniem znormalizowanych ról społecznych. Wpływały na zakres i formy ekonomizacji niepełnosprawności. Kształtowały terminologię, wyjaśnienia przyczyn i znaczeń skutków dysfunkcji. Określały poziom zaangażowania państwa w rozwiązywanie problemów osób niepełnosprawnych. Wpływały na 
charakter regulacji prawnych dotyczących interesującej nas grupy. Oddziaływały na zakres i poziom zaangażowania ludzi niepełnosprawnych i ich opiekunów w rozwiązywanie ich problemów.

Syntetycznej podstawy do dokonywania sygnalizowanych analiz dostarcza koncepcja Vica Finkelsteina [1980, 1993], rozwijana przez M. Olivera $[1983,1990]$ wzbogacona refleksją M. Foucoulta [1980] /i nieco bardziej szczegółowa, niemająca podstaw w neomarksizmie - teoria G. L. Albrechta [1976].

\section{Podejście tradycyjne. Epoka preindustrialna i industrialna}

Orientacja tradycyjna rozwijała się $\mathrm{w}$ okresie preindustrialnym i industrialnym - sięgając czasów ponowoczesnych. Historię społecznej lokalizacji osób z niepełnosprawnością zaczyna właśnie się od czasów starożytności, a konkretnie Grecji, z jej idealizowaniem kształtów ciała i sprawności fizycznej, supranaturalizmem w wyjaśnianiu przyczyn /przekroczenie tabu/ i przyzwoleniem na eksterminację istot zdeformowanych. W wiekach późniejszych życie codzienne i kultura ludowa były przesiąknięte wierzeniami łączącymi niepełnosprawność ze złem lub złymi uczynkami. Źródła pokazują, że np. niepełnosprawność bywała przedmiotem kpin, czasem litości, a także budziła lęk [Ryan, Thomas, 1980; Barnes, 1997]. Przyzwalano na eksterminację istot zdeformowanych i odmiennych [Barnes, Mercer, 2007; Frazier, 1969; Sumner, 1996; Zaleski, 1996]. Jednak osoby te lokalizowano w głównym nurcie życia. Miejscem ich obecności bywał cyrk, domy ludzi bogatych /tradycja utrzymywała się dość długo - do czasów rozwoju kina/ ale pełnili role niskie statusowo.

Wyjaśnienia przyczyn niepełnosprawności miały charakter supranaturalny. Odwoływały się do przekroczenia tabu np. w formie wykonywania zakazanych czynności. Dysfunkcja była znakiem zmazy i grzechu [Douglas, 2007]. Na przykład powątpiewano w człowieczeństwo osób z wadami wrodzonymi. Uwidaczniał się silny biologiczny determinizm - kierunek, który nadmiernie mocno wiązał fizyczność z psychiką [Lukrecjusz, Arystoteles, Juwenalis, cyt. za: Korniszowski, 2003].

Nadejście średniowiecza $\mathrm{z}$ jego dualizmem i negacją ciała przyniosło pewne zmiany w ustosunkowaniach do niepełnosprawności. Oficjalną wykładnię stanowiły poglądy św. Augustyna wskazujące, iż człowiek z dysfunkcją jest dziełem bożym, jak to podkreślał cytowany autor $\mathrm{w}$ dziele O państwie bożym. Nieoficjalnie zaprzeczano człowieczeństwu i uzmysławiano potrzebę eksterminacji istot, których wygląd i sposób funkcjonowa- 
nia odbiegał In minus od przeciętnej miary. Nadal jednak przyzwalano na obecność ludzi z deformacjami wrodzonymi w głównym nurcie z pełnieniem ról niskich statusowo [Gleeson, 1999: 179-202; Olivier, 1990].

Ponieważ brak było ingerencji państwa i regulacji prawnych gwarantujących jakieś formy pomocy, ludzie ci lub ich opiekunowie musieli sami zarabiać na swoje utrzymanie i czynili to, pracując w gospodarstwach przydomowych lub żebrząc na ulicach, eksponując swoją inność w menażeriach [Korniszkowski, 2003]. Podobna sytuacja zdarza się i dziś w krajach wyniszczonych wojną, w krajach mających status rozwijających się [Frąckiewicz, 1999].

W zależności od rodzaju dysfunkcji i jej nasilenia w zbiorowości różny był stopień wykluczenia. Na przykład praca Groce [1985] dotycząca małej, wyizolowanej społeczności, żyjącej na wyspie Martha’s Vineyard, pokazuje wysiłek włączenia do społeczności stosunkowo dużej liczby osób niesłyszących. Co istotne, spora część słyszących nauczyła się języka migowego. Do dziś niesłyszących otacza relatywnie mały dystans społeczny - są oceniani jako dobrze rokujący, podobni.

Kapitalizm, zwłaszcza w XIX wieku, przyniósł kolejną zmianę jakościową - wyrażającą się w tworzeniu wizerunku niepełnosprawności jako „tragedii osobistej”. Mechanizacja pracy, presja na szybkość, wymuszona dyscyplina, normy czasowe i produkcyjne powodowały usuwanie niepełnosprawnych $\mathrm{z}$ głównego nurtu pracy i zatrudnienie $\mathrm{w}$ chałupnictwie, w rzemiośle [Geelson, 1999]. Ciało niepełnosprawne stało się ciałem mało wydolnym. Ponadto, upowszechnianie umiejętności czytania i pisania podkreśla znaczenie pewnych dysfunkcji, jak np. głuchoty. Powstawały pierwsze szkoły specjalne.

Wzrastało znaczenie roli nauki w wyjaśnianiu genezy wad wrodzonych. Pojawiały się wyjaśnienia bardziej racjonalne, adekwatne do poziomu ówczesnego rozwoju wiedzy. Zaistnienie wady wrodzonej próbowano wyjaśniać bardziej naukowy sposób - wiązano jej zaistnienie z trybem życia, z konkretnymi czynnościami, jak np. „zapatrzenie się”, „przestrach” [Linneusz, cyt. za: Korniszowski, 2003], choć z punktu widzenia dzisiejszej wiedzy takiej wyjaśnienia są wątpliwe. Osoby z wadami wrodzonymi były przez pierwszych ewolucjonistów rozpatrywane jako wczesne stadia rozwoju człowieka [Down cyt. za: Stratford, 1993]. Podejścia Galtona, Linneusza wskazywały drogę do ukształtowania się homo sapiens w dzisiejszym pojmowaniu. Na dole drabiny tkwił człowiek monstrum, kolejno był to człowiek czarny, żółty i czerwonoskóry, wreszcie na samym szczycie człowiek 
biały - ideałem był oczywiście pełen umiaru, wyposażony w mieszczańskie maniery Europejczyk. Niepełnosprawni byli prezentowani jako mutanci [Stratford, 1993]. Eugenika podkreślała związki między zjawiskami patologii społecznej a dysfunkcjami fizycznymi i psychicznymi [Plotz, 2008; Ternon, Hellman, 1984].

Od XVII wieku w niektórych krajach miały miejsce początki ideologii państwa opiekuńczego, które zaczynało ingerować w rozwiązywanie problemów ludzi niepełnosprawnych [Blaxter, 1976; Stone, 1985]. Cytowane autorki wskazywały na nadawanie bytu prawnego niepełnosprawności - od powstałego w 1601 roku Prawa ubogich w Anglii, wprowadzającego podział na tych, którzy sami ponoszą odpowiedzialność za swoje złe położenie oraz na tych, którzy są biedni nie z własnej winy i zasługują na wsparcie. Osoby $\mathrm{z}$ niepełnosprawnością były klasyfikowane jako te, którym należy pomóc - byli to "chorzy, chorzy umysłowo, ułomni oraz starzy i niedołężni”. $\mathrm{Na}$ przestrzeni kolejnych dwóch stuleci doszło do poszerzenia tej kategorii. Regulacje te prowadziły do wykluczenia tych grup z głównego nurtu życia zbiorowego. Wiodły kolejnych ludzi do zamykania w specjalnych ośrodkach i poddawania społecznej opresji w formie kulturowego imperializmu, przemocy, wyzysku, marginalizacji, uświadamiania bezsiły [Young, 1983]. Niepełnosprawni byli w ten sposób kolonizowani na podobieństwo innych mniejszości [Glideman, Roth, 1980]. Doświadczali kulturowego imperializmu, przemocy, wyzysku i marginalizacji. Miejscem ich pobytu stawały się specjalne instytucje pomocowe oraz objazdowe menażerie, jak np. cyrk Barnuma. W XVIII wieku powstały liczne zbiory okazów fauny i flory, także kolekcje „monstrów” (zwykle ciężkie wady płodów i noworodków). Modne było odwiedzanie tych muzeów osobliwości; uwiecznił to Karol Dickens [1841] w powieści The old curiosity shop. Wtedy też zapoczątkowano segregację i izolację na szeroką skalę [Cohen, Scull, 1979; Tomlinson, 1982; Gordon, Humpries, 1992]. Rozwój nauki i narzędzi badawczych miał i inny wydźwięk. Pozwalał na precyzyjne wyodrębnianie i klasyfikowanie ludzi odmiennych $\mathrm{z}$ kwalifikowaniem do instytucji specjalnych.

Wcześniej, w społecznościach wczesnonowożytnych ludzie szukali pomocy u różnej „maści” znachorów i medyków [Pelling, 1998]. Od początku XIX wieku klasyczna, profesjonalna medycyna nakładała temu kres. Jej dominacja wynikała nie tylko $\mathrm{z}$ rozwoju nauki, ale i umacniania medycyny przez praktykowanie w specjalnie tworzonych miejscach. Wzrastał dystans między laikami a specjalistami. Lekarze i inni specjaliści obejmowali kontrolę nad edukacją, szkoleniem fachowców [Jewson, 1976: 225-244; Larson, 
1977]. Zaangażowanie medycyny w problemy niepełnosprawności (lub też przykładanie kryteriów medycznych do rosnącego zestawu problemów społecznych) pojawiło się jako kluczowy aspekt społecznej kontroli nad osobami niepełnosprawnymi.

Niepełnosprawność z medycznego punktu widzenia była sprawą jednostki, problemem psychosomatycznym, była sprowadzona do indywidualnego ograniczenia sprawności lub do innych „defektów” - jej osobistą tragedią, wymagającą wiedzy i praktyk medycznych.

Dokonała się instytucjonalizacja niepełnosprawności i choroby. Przedstawiciele medycyny zyskali monopol na leczenie. Państwo szkoliło i szkoli do dziś fachowców. Buduje ich autorytet [Jewson, 1976: 225-244; Larson, 1977]. Efektami tych działań były segregacja i izolacja ludzi chorych i niepełnosprawnych w placówkach medycznych, zakładach opieki i szkołach specjalnych (najpierw niesłyszących potem „słabych na umyśle”). Miała dobrze świadczyć o trosce o obywatela [Cohen, Scull, 1983] o rozwoju edukacji [Tomlinson, 1982; Gordon, 1992; Wintzer, 1993].

Trwająca do dziś profesjonalizacja zawodów związanych z niepełnosprawnością i chorobą - miała też swoje negatywne oblicze. Profesjonaliści upośledzali według Illicha [1997], swoich klientów. Istotne znaczenia miała najpierw diagnoza, prowadząca do etykietyzacji i zmiany statusu a potem do odizolowania i zmarginalizowania jednostek uznanych za niespełniające społecznych oczekiwań, a zarazem takich, których funkcjonowanie uważano za zagrażające interesom większości [Dartington, 1981; Freidson, 1970; Goffman, Sumner, Modrzewski, 2000; Safilios-Rothschild, 1970; Tomliss, 1982], a także za osoby uznawane za nierokujące spełniania zadań ważnych dla zbiorowości [Buss, 2001; Brannon, 2002; Katz, Kleck, Ono, Snyder, Mitchell, 2001: 367-389; Perlman, Routh, 1980: 43-55; Fine, Asch, Zebrowitz Solomon, Greenberg, Pyszczyński, 1993].

Nadal powiększał się dystans między specjalistami i laikami. Powszechne było nierównościowe traktowanie samych ludzi niepełnosprawnych i ich opiekunów. Specjaliści przejmowali nad nimi kontrolę [Parsons, 1987]. Instytucje medyczne, np. kliniki, stawały się instytucjami totalnymi [Foucault, 1999]. Z zapałem wynajdowało nowe kategorie „innych” i tworzono dla nich odrębne instytucje podtrzymujące ich zależność i uprzedmiotawiające i uzmysławiające słabość [Freidson, 1970; Scott, 1979; Goffman, 1963; Hunt, 1966; Zola, 1993: 5-17].

Typowe dla orientacji tradycyjnej utożsamianej z etnocentryzmem jest uwzględnianie istnienia podziału innych-obcych opartego na klarownych 
kryteriach podobieństwa lub różnicy $\mathrm{w}$ zakresie wieku, płci, orientacji seksualnej, na przejawianiu i prezentowaniu cech pozwalających na przetrwanie gatunku, na posiadaniu ważnych życiowo cech jak zdrowie, siła, proporcje budowy, kompetencje gatunkowe-poruszanie się na dwu nogach, komunikowanie się za pomocą mowy. Inspirująca jest tu praca Zbigniewa Benedyktowicza [2000; por. też Gobineau, 1856], u którego „Inny - niepełnosprawny" był lokalizowany na granicy świata ludzi i zwierząt. Wzbudzał specyficzne reakcje - był identyfikowany, klasyfikowany, opisywany, segregowany zależnie od wieku, płci. Kiedyś eliminowany, potem separowany - umieszczany w specyficznych nacechowanych obszarach (bagien, mgieł, tajemniczych wysp, ośrodków specjalnych, kiedyś np. domów szaleńców, leprozoriów) bywał marginalizowany. Człowiek z niepełnosprawnością budził niepokój, lęk, czasem wstręt, ale przede wszystkim fascynację. Podlegał stereotypizacji. Był nosicielem stygmatu-cechy ocenianej negatywnie. Był jednak zakorzeniany w społeczności. Był też autentyczny - inność czy to nabyta na skutek naruszenia normy społecznej (dewiacja) czy osiągnięta, czy przypisana była bytem sui generis naturalnym. Niepełnosprawność jako wariant inności na początku była uznawana za cechę immanentna, stałą nieeliminowalną. Inność miała charakter totalny - cechę inności rozciągano na całość zachowań i życia. Nieuzasadniona generalizacja widoczna i dziś w odniesieniu do niewidomych, do których mówi się głośno. Widoczna jest wobec przestępców, od których oczekuje się, że cały czas będą zbójować.

Inny był jednak konserwowany i to na różne sposoby - utrwalany w sztuce [Eco, 2007]. Inność miała specyficzny wydźwięk - mityczny, mistyczny, numinodyczny. Łączyła się ze sferą sacrum. Pokazuje owe prawidłowości np. Zbigniew Benedyktowicz [2000: 192]. Mając u podstaw wizerunki obcego w kulturze ludowej pokazał specyficzne kategorie obcych. Obcy to nie tylko „nieludzie” i zwierzęta, ale również kobiety i dzieci, osoby nieme, niewidome, o czarnym kolorze skóry, symbolizujące śmierć i jałowość, diabły, ale paradoksalnie, także bogowie. Kategoria „swój - obcy” staje się kategorią mistyczną, gdyż „Doświadczenie obcości wykazuje zasadnicze podobieństwo do struktury doświadczenia i przeżycia sacrum. Stosunek do tego, co obce ma charakter ambiwalentny; jest połączeniem grozy, niechęci i fascynacji”. Źródło inspiracji dla badań dotyczących inności stanowi także doktryna indywidualizmu, dowartościowująca rolę konsekwentnego budowania własnej tożsamości, kładąca nacisk na prawo do bycia wolnym i autentycznym (tak zbanalizowane przez współczesność) oraz ludzką umiejętność samodoskonalenia. „Inny” od samego początku 
balansował na granicy tego, co ludzkie i zwierzęce, traktowany był nieraz jako byt na marginesie człowieczeństwa, swoista hybryda cielesno-duchowa, w której cielesność brzydziła i prowokowała, a istnienie sfery duchowej było podawane w wątpliwość. Taki jest właśnie archetypiczny „inny”: Minotaur, potomek byka i kobiety

Kim jest zatem „inny” - jest opozycją wobec przedstawionej wizji Europejczyka (zarazem swego rodzaju idealnego człowieka). Wyposaża się go w cechy ponadnaturalne, jak i wynikające $\mathrm{z}$ instynktów, we właściwości budzące sprzeczne nastawienia - w cechy rodzące przerażenie, jak i fascynację. Obcy jest więc obdarzony nadmierną seksualnością, emocjonalnością, prymitywną mentalnością, duchowością. Kojarzy się z magią, animizmem i zwierzęcym erotyzmem [Fanon, 1992: 220-240]. Obcy może budzić podziw $\mathrm{z}$ powodu posiadania zdolności zaliczanych do sfery tabu (ukrywanych i chronionych) jak zdolności artystyczne, duchowe, erotyczne. Zarazem obcy wzbudza poczucie zagrożenia, gdyż jego atrybuty kwestionują omnipotencję nauki i racjonalności. Pokazują inne systemy wartości. Podważają status quo i wywołują lęk przed chaosem w kulturze Zachodu. Egzotyka „innego” zagraża intelektowi, moralności jak też porządkowi wielbionemu w zachodnim prawie [Joffe, cyt. za: Sztompka, 2008]. Kiedyś poszczególne rasy /sic, historyczna typologia Gobineau [1856], a dziś specyficzne rodzaje niepełnosprawności rodzą odmienne poziomy lęku i reakcje społeczne.

W kręgu kultury europejskiej „swój” jest nadal istotą rodzaju męskiego, intelektualistą ceniącym wiedzę naukową, postępowcem. Cechuje go opanowanie moralne, znajomość i stosowanie manier mieszczańskich. W jego myśleniu i działaniu widoczna jest samokontrola, racjonalność i indywidualizm, wysoka ocena piękna i porządku. I co ważne jest to człowiek zdrowy i sprawny [Barnes, Mercer, 2008; Heathertorn, Kleck, Hebl, Hull, 2008].

Inność - obcość współcześnie. Postindustrializm i postmodernizm. Nowe perspektywy dyskursu

W okresie obecnym, nazywanym postindustrialnym, pojawiło się inne podejście społeczeństw do osób niepełnosprawnych - dla którego wyjaśnienia użyteczna jest koncepcja Michela Foucaulta [1980]. Cytowany autor eksponuje rolę „wiedzy - władzy” nad ciałem. Przedstawia, jak wiedza i ideologie będące podstawą tworzenia instytucji wpływają na stosunek zbiorowości do chorych i niepełnosprawnych. Formułuje tezę, że ewolucja sposobu myślenia „od ciała kontrolowanego fizycznie do samodyscy- 
pliny" była podstawą tworzenia standardów normalności ciał i zachowań [Young, 1997: 147-160]. Rozdzielono ciało fizyczne od psyche. Dla każdej $\mathrm{z}$ dwu płaszczyzn stworzono odrębne standardy w różnym stopniu dotykające grup ludzi chorych i niepełnosprawnych.

Kult myśli racjonalnej eksponował odmienność chorych psychicznie. Społeczne konstruowanie choroby psychicznej [Inleby, 1983] wyrażało się wzrostem liczby specjalistów zajmujących się problemami zdrowia psychicznego, wyodrębnianiem typów zaburzeń, wkroczeniem psychiatrii do szkół, domów rodzinnych, miejsc pracy. Tworzeniem regulacji dotyczących zdrowia psychicznego, standardów nienormalnego zachowania oraz systemu profilaktyki i rehabilitacji zajmowali się [Castells, 1983; Miller, Rose, 1988; Davies, 1995].

\section{Socjopolityczny model niepełnosprawności}

Samoorganizowanie się osób niepełnosprawnych widoczne w krajach Europy Zachodniej (Związek Niepełnosprawnych Fizycznie przeciwko Segregacji) od lat siedemdziesiątych wieku doprowadziło do krytyk społeczeństwa jako instytucji tworzącej bariery i do oddzielenia pojęcia uszkodzenia od niepełnosprawności i upośledzenia [Finklestein, 1993]. Uszkodzenie jest defektem na poziomie organicznym, niepełnosprawność jest skutkiem barier tworzonych przez społeczeństwo, ograniczeniem o charakterze funkcjonalnym wykazującym zależność socjokulturową, upośledzenie jest łącznym skutkiem uszkodzenia i niepełnosprawności.

Ten rodzaj myślenia proponuje zamiast indywidualnego trybu rehabilitacji i opieki wprowadzenie szeroko zakrojonych zmian połączonych $\mathrm{z}$ alternatywnymi formami wsparcia i opieki [Finkelstein, 1993]. Wymaga programu działań politycznych pozwalających przezwyciężać opresję społeczeństwa [Finklestein, 1993; Olivier, 1983; Abberley, 1987].

Opisywana zmiana podejścia do niepełnosprawności, choć stanowiła krok naprzód, została poddana krytyce ze strony ludzi niepełnosprawnych. Akcentowali oni dominację definicji medycznych i stosowanie biofizjologicznych kategorii normalności. Nie uwzględniały one wpływu społecznych kryteriów oceny wagi i kształtu ciała. Nie brały pod uwagę relatywizmu kulturowego i społecznego w przyporządkowywaniu ról społecznych [Wendell, 1996].

Twierdzili, iż uszkodzenie określane jako przyczyna niepełnosprawności uprzywilejowuje medycynę i usprawiedliwia dominację personelu 
medycznego i specjalistów w życiu osób niepełnosprawnych. Tymczasem ludzie niepełnosprawni coraz częściej twierdzą, że niepełnosprawność (widziana $z$ perspektywy społecznej) nie jest problemem zdrowotnym, stąd profesjonaliści zajmujący się zdrowiem nie są najlepszymi do udzielania pomocy niepełnosprawnym. Trzeci argument przeciw klasyfikacji WHO - definicje nie biorą pod uwagę stopnia opresyjności barier społeczno-kulturowych.

W wielofunkcyjnym systemie klasyfikacji zachowano kategorię „uszkodzenia funkcji i struktury organizmu”, ale zastąpiono pojęcie niepełnosprawności kategorią działania, a pojęcie upośledzenia - kategorią uczestnictwa. Podejście takie wskazuje, iż jest wiele czynników środowiskowych wpływających na działanie i funkcjonowanie człowieka w społeczeństwie. Podejście takie otwiera nowe perspektywy badań - np. jak poszczególne środowiska, w których człowiek żyje kształtują jego szanse uczestnictwa [Hurst, 2000: 1083-1087].

\section{Legislacja}

Druga połowa XX wieku przyniosła rozwój różnego typu praw na rzecz osób niepełnosprawnych zakazujących dyskryminacji, nakazujących traktowanie równościowe.

Sticer [1982] argumentuje, że właśnie legislacja tworząc definicje, kryteria i stopnie niesprawności dała słabości egzystencję i status, jakiego kiedyś nie miała. Obdarowała ludzi niepełnosprawnych podwójną tożsamością społeczną - po pierwsze jako ludzi skrzywdzonych, uszkodzonych; po drugie - jako obywateli, którym przysługują te same prawa, co ludziom pełnosprawnym. A jednak ludzie niepełnosprawni i tak są ograniczani [Murphy, 1987]. Ich życie obudowuje się specjalnym przemysłem, specjalistami, procesami klasyfikacji, chociażby przy przyznawaniu rent. Oczywiście, w różnych krajach wypracowane są odrębne kryteria przyznawania rent- np. w USA mogą rentę uzyskać osoby cierpiące stały ból, w krajach skandynawskich - zarejestrowani alkoholicy.

\section{Terminologie}

Krytyka określeń synkretycznych, czasem o medycznym rodowodzie, doprowadziła do poszukiwań terminologii pokazujących równowartość 
odmienności, zhumanizowanych, niedeprecjonujących. Jednak i te nowe pojęcia zyskują wydźwięk pejoratywny, gdyż kojarzą się z utratą zdrowia.

\section{Ekonomizacja i ekonomiczna wizja niepełnosprawności}

Z punktu widzenia ekonomii niepełnosprawność jest funkcjonalna. Ludzie wierzą w sens innowacji technologicznych, dzięki czemu, w dobie postindustrializmu niepełnosprawność i choroba stała się zyskownym interesem. Widoczny jest rozwój instytucji, usług, technologii [Albrecht, 1992; Russel, 1998]. Ma miejsce szczególna dwoistość sytuacji - rośnie liczba ludzi uznawanych za potrzebujących opieki, a zarazem uznawanych za takich, którym się ona słusznie należy, ale zwiększają też koszty tej opieki, więc państwo próbuje oszczędzać [Williams, 1990].

\section{Cielesność i technologizacja niepełnosprawności}

W postindustrialnym społeczeństwie istotne znaczenie ma, poza psychiką, cielesność. Kryterium cielesne jest kluczowe dla przedstawienia cech osobowości i walorów moralnych [Crawford, 1980]. Posiadanie ciała i bycie ciałem znajduje się w centrum naszej autokreacji, kapitał cielesny jest traktowany jako istotny element kapitału kulturowego - $\mathrm{z}$ jego pościgiem za pięknem i sprawnością [Turner, 1992]. Turner [1992] używa wręcz terminu „społeczeństwo cielesne”, a Seymur [1998] mówi o ciele jako „ikonie współczesnego konsumpcjonizmu".

Zmieniły się funkcje ciała - $\mathrm{z}$ ciała nadającego się do pracy stało się ono ciałem spełniającym oczekiwania społeczeństwa konsumpcyjnego. Co więcej, ciało jest traktowane jako przedmiot wyboru, gdyż nowoczesne technologie dają szereg możliwości jego modyfikacji [Shiling, 1993]. Wyglądający typowo też chcą skorzystać na technologiach. Jedni są niezadowoleni z wyglądu w całości, inni częściowo. Jedni zlecają wykonanie tatuażu upodabniającego ich do tygrysa, pantery lub wilka. Starsi próbują się odmłodzić, młodsi postarzeć. Chyba silnie to widać w wyborach małej miss, we fryzurach, kreacjach i makijażu kilkuletnich dziewczynek.

W szczególny sposób zalecenie kształtowania ciała dotyczy osób z widocznymi deformacji i dysfunkcjami. Ludzie ci powinni przynajmniej podjąć próbę odtwarzania ciała i odzyskania osobowości przedurazowej przy użyciu pomocy technicznych. Rzadko uwzględnia się tu jednak psychologiczne koszty zawiedzionych nadziei [Seymur 1998]. 
Człowiek przyszłości jawi się jako istota półludzka [Haraway, 1991] cyborg - czy „przekładaniec” Stanisława Lema. Technologie mają jednak i jasną stronę się. W efekcie ich użycia pewne kategorie, jak np. niewidomi, stają się mniej niepełnosprawne [Finkelstein, 1980]. Ponadto rozwój technik rehabilitacji medycznej pozwala na odzyskanie zdolności chodzenia i ukrywanie niepełnosprawności.

\section{Główny nurt}

Pojawiły się też nowe praktyki, jak krytyka instytucji zamkniętych [Townsend, 1967; Martin, 1985; Tarkowska, 1996; Goffman, 1961] - głównie domów opieki i szpitali psychiatrycznych [Humpries, Gordon, 1992; Miller, Gwynne, 1972]. Wielu autorów wskazywało, iż szpitale powodowały uzależnienie chorego [Wolfensberger, 1989].

Odbywa się stopniowa likwidacja dużych instytucji, co wynika z chęci ograniczenie kosztów utrzymania, a także z postępów farmakologii, która umożliwia kontrolę pacjenta poza szpitalem i pozwala na głębszą integrację chorego ze środowiskiem [Scull, 1984; Busfield, 1986]. Tworzone są też mniej formalne ośrodki [Russel, 1998]. Powstają zakłady opieki bardziej „oświecone” z inicjatywy rodziców dzieci z pewnymi dysfunkcjami [Croft, Beresfrod, 1992].

\section{Normalizacja}

W sferze oficjalnej ma miejsce polityka normalizacji [Bank-Mikkleson, 1980]. Normalizacja życia osób poszkodowanych na zdrowiu nie jest dorobkiem XX wieku ani kultury euroamerykańskiej. W opisywanej już społeczności Masajów wszystkie dzieci poddawane są tym samym obrzędom i rytuałom [Talle, 1994].

Wskazywane są grupy, których interesy były pomijane, generujące w społecznym mniemaniu przymioty słabości. Taką kategorią są niepełnosprawne kobiety. Wymusza się na nich bierną zależność, swoistą bezpłciowość, nieinteresowanie się wyglądem [Begum, 1992: 70-84], wykluczenie z pracy [Asch, Fine, 1988], zniechęcane do macierzyństwa [Finger, 1992; Thomas, 1997], edukacji, ograniczane w systemie poradnictwa.

Kobiety takie bywają traktowane jako mniej wartościowe niż pełnosprawne, wykluczone $\mathrm{z}$ dyskursu o niepełnosprawnych i z dyskursu femi- 
nistycznego [Begum, 1992: 70-84]. Traktuje się je jako mniej kompetentne i nieodpowiednie na żony pełnosprawnych mężczyzn.

\section{Praktyka życia ponowoczesnego}

W dobie ponowoczesności pewne zjawiska stają się mniej przejrzyste. Granice między normą i odmiennością stają się płynne. Pewne dysfunkcje zdają się tracić deprecjonujący wydźwięk. Sama inność podlega fragmentaryzacji lub segmentyzacji. Jest fałszowana i traci swój niepowtarzalny charakter. Człowiek, między innymi, dzięki zdobyczom nauki -medycyny technologii (biotechnologii) regulacjom prawnym może zmieniać sam siebie Jak pisał Baurillard - jest bytem typu „ready made” lub jak to określa Z. Melosik - może być każdym. Pojawia się deficyt prawdziwej inności w społeczeństwie medialnym, w społeczeństwie spektaklu - wśród ludzi spragnionych nowości i inności .

Pojawiają się nowe azyle. Ludzie sami izolują się od obcych - choć na ich byt przyzwalają. Tworzą nowe wspólnoty w zamkniętych, otoczonych murami, strzeżonych osiedlach. Nie ma na ich ulicach żebraków. Są sami relatywnie zamożni, cywilizowani. Problemy społeczne, których są znakiem zostały też skreślone z listy świadomie przeżywanych zagrożeń. Nie dzieje się jednak tak, jak chcieli optymiści - nie zachodzi proces „skapywania" bogactwa i rozszerzania się kręgu zamożności [Bauman, 2011]. Duch równości błąka się po zaświatach, choć są przykłady rozwiązań umożliwiających mu zstępowanie na Ziemię [Wilkinson, 2011]. W dobie społeczeństwa spektaklu i oficjalnego przyzwolenia na inność inny - niepełnosprawny jest demitologizowany Jego wyjątkowość jest przemijająca, względna i częściowa (płynna - Bauman). Pojawia się wręcz przymus terapeutyzacji i technologizacji. Niepełnosprawny jest ulepszany. Nie ma kolejnego wcielenia bogini Lakszmi - jest przypadek dziewczynki z wadą wrodzoną, której skutki należy usunąć. Odarta z boskości ma wieść zwykłe życia. Możliwy jest też inny proces - ze zwykłego, typowego można zmienić się na własne życzenie w wyjątkowego. Jest on jednak ,innym” nieautentycznym - jest klonem odtwarzającym inność - bo na wszelkie odmienności jest zapotrzebowanie. W czasach hiperrzeczywistości i powszechnej obecności mediów inność jest stałym elementem życia. Realne życie zostało zastąpione teatralnym, prawdziwa inność została zastąpiona sztuczną. Sztuczna inność jest bowiem bezpieczna. Ludzie ją tworzą i wierzą, że nad nią panują. Doznają złudy poczucia bezpieczeństwa i złudy stabilnej i har- 
monijnej tożsamości. Człowiek, jak pisze Debond [za: Bauman, 2011], pozostaje spełniony wirtualnie, ale wyalienowany realnie, pozbawiony więzi w świecie symulacji komputerowych kosmitów i przetworzonych, hodowanych własnym sumptem i w sobie dziwolągów. Odpowiedzią jednostki jest zagubienie, niepewność, konflikty [Bauman, 2011]. Cechą jednostek jest - podobnie jak cechą przekazów medialnych - homogenizacja, przemieszanie i ujednolicenie. Wątek fałszywej inności jest nader wyeksploatowany. Jest to byt konsumowany, przetwarzany, nienacechowny, bez swoistej przestrzeni - ów baumanowski turysta. Można urodzić się jako kobieta lub hermafrodyta, a potem stać się mężczyzną i urodzić dziecko.

Niepełnosprawność jako wariant inności nie ma swojego stałego miejsca. Uległa rozproszeniu. Nie ma dla niej miejsca w inności świątyni, na uroczysku, w azylu. Wędruje ulicą. Nie wiadomo, czy tak spospolitowaną ktoś zauważy. Teraźniejsi „inni” wyszli z zaklętych miejsc, opuścili azyle. Żyją obok nas. Stale budzą skrajne emocje, wśród nich lęk i fascynację. Należy zauważyć, iż „inni” - to nie tylko, głównie nie-Europejczycy czy niepełnosprawni. To również „inni” rozumiani w duchu Lévinasa: $z$ tej samej białej rasy i z tego samego, zachodniego kręgu kultury", to także obcy w nas, demaskujący, zgodnie z koncepcją Julii Kristevej, wewnętrzną niespójność jednostki. Zresztą odkrycie tej niepokojącej, immanentnej sprzeczności, „cudzoziemskości” na własnej ziemi, czeluści w samym sobie autorka Strangers to ourselves uznaje za jedną z istotnych przyczyn kryzysu indywidualizmu - promującego człowieka jako spójną, stabilną i harmonijną konstrukcję [Zdanowicz-Cyganek, 2010]. Czy jednak już tak jest jak chciał Fryderyk Nitsche piszący „Zaistniała możliwość stworzenia międzynarodowych związków rasowych, których celem będzie wyhodowanie rasy panów przyszłych „władców Ziemi” nowej, wielkiej arystokracji... wyższego rodzaju ludzi, którzy dzięki swojej niezrównanej woli, wiedzy, bogactwu, wpływom posłużą się demokratyczną Europą jako swoim najbardziej giętkim narzędziem, aby jak artyści tworzyć samego człowieka. $\mathrm{Na}$ dylematy wskazuje Francis Fukuyama. Pokazuje szerszy kontekst nowości - nowe wyzwania genetyki-czy zmierzch człowieka. W jego wydaniu realne i konkretne, urzeczowione staje się sformułowanie „non omnis moriar” - technika pozwala zachować geny, narządy, ale czy już i ducha człowieka, jak to było w opowiadaniu St. Lema Przekładaniec. Inny w przyszłości może być chimerą będącą skrzyżowaniem człowieka i zwierzęcia. Tak niedawno naukowcy umieścili ludzkie DNA w krowim oocycie i doprowadzili do stadium blastocyty. 
Cały czas aktualne jest pytanie o znaczenie inności. Jest ono tym ważniejsze, im współcześni prorocy wskazują, iż długotrwałe konflikty będą coraz częściej powstawały wokół „przypisanych” cech, które obecnie tak jak dawniej związane są z upośledzeniem: rasa, kolor skóry, płeć, przynależność etniczna (bycie robotnikiem cudzoziemskim), wiek, kalectwo. Tego rodzaju nierówności społeczne, które są „quasi-przekazane przez naturę w warunkach zaawansowanej indywidualizacji otrzymują szczególne szanse organizacyjno - polityczne. Dzieje się tak z powodu ich nieuchronności, trwałości, sprzeczności z zasadą sukcesu, konkretności i dzięki temu, że są bezpośrednio rozpoznawalne. Wszystko to umożliwia procesy identyfikacji. Na plan pierwszy wysuwają się przy tym dwa epokowe tematy: położenia zagrożenia /globalnego/ społeczeństwa ryzyka i sprzeczności pomiędzy kobietami i mężczyznami, które do tej pory były związane z rodziną." Można więc mniemać, iż w szczególnie trudnej sytuacji znaleźć się mogą osoby generujące skutki wielorakich przypisanych symptomów słabości - np. niepełnosprawni dotknięci złożonymi dysfunkcjami. Ta kategoria społeczna stanowi i stanowić będzie grupę „nowych obcych” [Bauman, 2011: 51-61].

\section{A jednak pozytywy fenomenu niepełnosprawności}

Niepełnosprawność jako wariant inności (na podobieństwo dewiacji), sztuczna czy naturalna, jest potrzebna. Zaspokaja szereg potrzeb jednostkowych i społecznych. Już studia historyczne i te zorientowane ku współczesności, a jeszcze bardziej analizy komparatystyczne, porównywane do wielkiej podróży, wzbogacają człowieka wsłuchującego się w głosy przedstawicieli innych epok i kultur. Sprzyjają kształtowaniu się tożsamości. Kształtujemy swój obraz porównując się z innymi ludźmi albo z sobą samym na różnych etapach cyklu życia. Lepiej nawet być kimś złym, niż być nikim - nie wiadomo kim [Erikson, 1968]. Mamy możliwości określenia siebie i znalezienia grupy odniesienia, w której czujmy się bezpiecznie - jakby to poczucie nie zbyło złudne - ale pozwala nam żyć [Czapiński, 2001].

Świadomość inności wzbudza postawę refleksyjności i aktywności poznawczej, emocjonalnej, behawioralnej. Czasem „Ubieranie się w inność” i włożenie maski ma wymiar ochrony. By być akceptowanym, człowiek osłania ego przed światem, zasłona jedynie coś skrywa, lepiej coś ukryć niż stracić - prawdę jednostki o niej samej. Oczywiście są znane i negatywne efekty maski: zamiast bliskości i ochrony osiąga się zwiększenie niepokoju. Wśród podobnych efektem świadomości istnienia „innych” 
jest podnoszenie poczucia własnej wartości, kształtowanie więzi grupowej, orientacja w świecie i poczucie bezpieczeństwa.

$\mathrm{Na}$ niepełnosprawności i cierpieniu znakomicie się zarabia i to w różny sposób. Zarobkują specjaliści zajmujący się odmieńcami - lekarze (chirurdzy kosmetyczni i nie tylko oni). Normalny chory ma poddać się leczeniu a sam sobie nie poradzi... Pomagać mu będą pracownik socjalny, nauczyciel (dziecko to też inny obcy w kulturze dorosłych) i władze oświatowe. Wyodrębnione stare i nowe kategorie osób ze specjalnymi potrzebami wchodząc do szkół masowych wymagają wsparcia już nie jednego nauczyciela ale zespołu. Co więcej, sama reforma wymaga monitorowania - a to zadania dla naukowców i praktyków a także wyzwanie dla konstruowania modelu życia odmieńców. Pytamy, czy edukacja doprowadzi do autentycznego scalenia społeczeństwa. Pytamy, gdyż mamy wątpliwości. Pytamy, bo mamy na uwadze, iż być może pewne zjawiska (niechęć, dystans, stereotypizacja i stygmatyzacja) zostały tylko przeformułowane, ubrane w elegancki język egalitaryzmu. Nadal istnieje ukryty rasizm w warunkach konfliktu interesów i jego skutków socjoekonomicznych. Do szkół specjalnych, które znacząco zmieniają swój charakter trafiają dzieci z coraz bardziej złożonymi deficytami - im też ma pomagać zespół. Badania własne autorki dotyczące percepcji inności wśród nauczycieli pokazują, iż konstruowane są linie podziałów na bazie stereotypów zakorzenionych w ludzkiej świadomości. Rzutują one na formalne i pozaformalne działania podejmowane wobec istot uważanych za odmienne. Kryterium różnicowania społecznej reakcji jest stopień inności (zaburzenia). Wszelka inność nadal budzi obawę i niechęć. Jako niepokojące, problemowe uważa się np. dziecko 5 - letnie bez uśmiechu, nieruchliwe, posiadające rozległą wiedzę, nieufne i poważne, wyłączające się z życia grupy, której nie lubi. Normalne dziecko jest gotowe do współpracy i dialogu, otwarte, wesołe, uśmiechnięte, ciekawe świata, głośne, potrafiące marzyć, z wyobraźnią, posłuszne, przyjazne, zna zasady, grzeczne, rozmawia na temat, samo potrafi się zająć, szczęśliwe, ciche, łatwo wyraża uczucia, ufne (cytaty).

Krocie zgromadzą przemysłowcy produkujący pomoce techniczne, leki i inne rzeczy. Zarobią ludzie sztuki i kultury masowej tworząc inności o nowych obliczach. Inność wyzwala więc potencjały kreatywności - inne spojrzenia na rzeczywistość. Skłania ku empatii - do poszukiwania zrozumienia, do emergencji pojmowanej jako nowa jakość stosunków międzyludzkich. Inność to temat do dyskursu i asumpt do poszukiwań jej wyrażania, do wzbogacani słownictwa, do konstruowania nowych, alternatywnych stylów życia i nowych wspólnot nowych obcych „głuchych po treningu mówienia”. Od- 
mienność implikuje poszukiwania. Rodzi pytania, czy dobrze jest być obcym i odmiennym. Jaki obcym, jakim odmiennym warto być.

Inność jest powszechna i ożywcza. Odznacza się kontekstowością i wielością oblicz. Jednak pewne zjawiska - ekonomizacja życia, wysoka ocena racjonalnego myślenia, indywidualizm, umiejętności zwycięskiej rywalizacji, nowa eugenika rodzą nowe podziały i tworzą nowych obcych, którzy są potrzebni. Równi nie znaczy bowiem jednakowi.

\section{Wnioski}

Badania w obrębie nauk humanistycznych (etymologia, lingwistyka stosowana) oraz studia społeczne uporządkowane według kryterium horyzontalnego i wertykalnego pokazują dwie tendencje w podejściu do niepełnosprawności jako inności-obcości. Jedną z nich można nazwać klasyczną lub tradycyjną, drugą - ponowoczesną. Obie są pochodną rozwoju wiedzy, procesu industrializacji, ruchów na rzecz praw człowieka, czynników ekonomicznych, autonomii jednostki. W podejściu tradycyjnym niepełnosprawny - inny był autentyczny. Tworzyła go, mówiąc kolokwialnie, natura. Był istotą niepowtarzalną, wyjątkową, nacechowaną, znaczącą, będącą ostrzeżeniem, a na pewno swego rodzaju znakiem, słupem granicznym. Jednak choć dawano mu mniejszą wartość i wpisywano weń gorszą jakość, był emanacją świętości i mocy chaosu, z której miał wyłonić się ład. Był niedookreślony. Nosił zmazę, swego rodzaju brud [Douglas, 2007]. Jednak budził podziw niezwykłymi zdolnościami, zaliczanymi do sfery sacrum, cech numinodycznych [Benedyktynowicz, 2000], jak nadmierna seksualność, emocjonalność, duchowość, związki z magią, prymitywna mentalność, związki z animizmem i zwierzęcym erotyzmem [Fanon, 1992: 220-240]. Miał zdolności ukrywane i chronione - zdolności artystyczne i duchowe [Dilthey, 1957]. Budził zagrożenie, gdyż te atrybuty kwestionują omnipotencję nauki i racjonalności, pokazują inne systemy wartości, podważają status quo i wywołują lęk przed chaosem w kulturze Zachodu. Odmieniec posiadał niezbywalne, stałe cechy ponadnaturalne, jak i wynikające $\mathrm{z}$ instynktów, egzotykę innego, która zagraża porządkowi wielbionemu w zachodnim prawie, intelektowi i moralności [Joffe, 2010]. Inność nazywano wprost. Żyła w słowie. Dowodem są pseudonimy władców np. Laskonogi, Łysy, Krzywousty, Łokietek. Postindustrializm przyniósł zmianę w podejściu do inności. Stała się powszechna, a zarazem płynna, czasowa. Istoty dotknięte innością wytwarza się dziś, gdyż są niezbędne w spo- 
łeczeństwie spektaklu. „Klony” stworzone ręką człowieka, z jego pomysłu są następnie konserwowane, przetwarzane i konsumowane. Odarto je z nacechowania. Są bytami wielofunkcyjnymi, jak James Bond, stworzony do zabijania i zabawiania. O odmienności, zwłaszcza fizycznej, nie wypada mówić. Obowiązuje cielesna cisza.

Ewolucja ustosunkowań ma charakter bardziej kołowy niż liniowy. Ludzkość, zdaje się, co jakiś czas wraca do wcześniejszych koncepcji. Dokonywane są przy tym modyfikacje zależne od cech porządku aksjonormatywnego zbiorowości. Osoby z rozmaitymi stygmatami inności są obecne w życiu zbiorowości, w tym w codziennym życiu instytucji edukacyjnych. Badania pokazują, że złudne jest myślenie o efektywności prostych rozwiązań i administracyjnego przymusu [Szumski, 2002]. Istotne jest, jak sądzę, prowadzenie badań nad scalającym wydźwiękiem edukacji włączającej. Sugerowane są badania nad innością nie wprost. Przydatna jest socjometria, ale i badania sięgające do koncepcji Bogardusa, analizy deferencjału semantycznego, studia nad kryteriami inności, normy, trudności, oczekiwania rodziców, dzieci, nauczycieli. Prowadząc działania eksploracyjne odpowiadamy sobie na pytanie o rację bytu pedagogiki specjalnej - czy już jest zbędna?

\section{Bibliografia}

Abberley P. (1987), The koncept of oppresion and the development of a social theory of disability, "Disability, Handicap and Socjety", nr 2.

Albrecht G.L. (red.), (1976), The Sociology of Physical Disability and Rehabilitation, Pittsburg, University of Pittsburg Press.

Ash A., Fine M. (1988), Intoduction: beyond pedestals, (w:) A. Ash, M. Fine (red.), Women with disabilities: Essey In Psychology, Philadelphia, Culture and Politics.

Bank-Mikkelson N. (1980), Denmark, (w:) R.J. Flynn, K.E. Nitsch (red.), Normalisation, Social Integration and Community Services, Baltimore, University Park Press.

Barnes C., Mercer G. (2008), Niepetnosprawność, Warszawa, Wydawnictwo Sic!

Bauman Z. (2010), 44 listy ze świata plynnej ponowoczesności, Kraków, Wyd. Literackie.

Bauman Z. (1992), Nowoczesność i zagłada, Warszawa, Biblioteka Kwartalnika Masada.

Bauman Z. (1996), Socjologia, Poznań, Wydawnictwo Zysk i S-ka.

Benedyktowicz Z. (2000), Portrety obcego. Od stereotypu do symbolu, Kraków, Wydawnictwo Uniwersytetu Jagiellońskiego. 
Boski P. (1992), O byciu Polakiem w ojczyźnie i o zmianach tożsamości kulturowo-narodowej na obczyźnie, (w:) P. Boski, M. Jarymowicz, H. Malewska-Peyre (red.), Tożsamość a odmienność kulturowa, Warszawa, Instytut Psychologii PAN.

Baudrillard J. (2006), W cieniu milczącej większości albo kres sfery społecznej, tłum. S. Królak, Warszawa, Wydawnictwo Sic!

Begum N. (1992), Disabled Woman and the feminist agenda, "Feminist Review", nr 40.

Blaxter M. (1976), The Meaning of Disability, London, Heineman.

Barron K. (1997), Disability \& Gender-Autonomy as an Indication of Adulthood, Uppsala University.

Buss D.M. (2001), Psychologia ewolucyjna. Jak wytłumaczyć społeczne zachowania człowieka. Najnowsze koncepcje, tłum. M. Orski, Gdańsk, GWP.

Castells M. (2009), Koniec tysiąclecia, Warszawa, PWN.

Chołuj B. (2004), Inność w powieściach Teodora Fontane, (w:) M. Janion, C. SnochowskaGonzalez, K. Szczuka (red.), Inny. Inna. Inne. O inności w kulturze, Warszawa, IBL.

Cohen S., Scull A. (red.), (1983), Social control and the State, Oxford, Blackwell.

Crowford R.C. (1980), Healtism and the medicalisation of everyday life, "International Journal of Health Services", nr 10 (3).

Czapiński J. (2001), Szczęście złudzenie czy konieczność? Cebulowa teoria szczęścia w świetle nowych danych empirycznych, (w:) M. Kofta, T. Szustrowa (red.), Złudzenia, które pozwalaja żyć, Warszawa, PWN.

Dąbrówka A., Geller E., Turzyński R. (1997), Słownik synonimów, Warszawa, Świat Książki.

Dartington T., Miller E. J., Gwynne G. (1981), A life Together, London, Tavistock.

Davies A. (1989), From Where I Sit:Living in an Able Bodied World, London, Triangle.

Debord G. (2006), Społeczeństwo spektaklu, tłum. M. Kwaterko, Warszawa, PIW.

Douglas M. (2007), Czystość i zmaza. Analiza pojęć nieczystości i tabu, tłum. M. Bucholc, Warszawa, PIW.

Erikson E.H. (1968 a), Identity, youth and crisis, New York, W.W. Norton.

Erikson E.H. (1968 b), Identity, psychosocial, (w:) International Encyclopedia of the Social Science, New York, Mcmillan and Free Press.

Fanon F. (1992), The Fact of Blackness, (w) J. Donald, A. Rattansi (red.), Race, Culture and Difference, London, Sage.

Finklestein V. (1993), The commonality of disability, (w:) J. Swain, V. Finkelstein, S. French (red.), Disabling Barriers-Enabling Environements, London, Sage.

Finger A. (1991), Past Due: A Story of Disability, Pregnancy and Birth, London, Women's Press.

Foucault M. (1993), Nadzorować i karać: narodziny więzienia, Warszawa, Aletheia.

Frazier N. (1997), Justice Interrupts: Critical Reflections on the "postsocialist" Condition, London, Routledge.

Frazier J.G. (1962), Złota gałąź, Warszawa, PIW.

Frąckiewicz L. (red.), (1999), Niepełnosprawni w środowisku społecznym, Katowice, Zeszyty Akademii Ekonomicznej im. Karola Adamieckiego. 
Frąckiewicz L. (2002), Postawy wobec niepełnosprawności, Katowice, Wydawnictwo Akademii Ekonomicznej im. Karola Adamieckiego.

Freidson E. (1970), Profession of Medicine, London, Harper and Row.

Fukuyama F. (2008), Koniec człowieka, Kraków, Wydawnictwo „Znak”.

Gajewska A., Pawlus M. (2003), Słownik synonimów i antonimów, Bielsko - Biała, PPU "Park".

Gleeson B.J. (1997), Disability Studies: a historical materialis view, "Disability and Society", nr 12 (2).

Gliderman J., Roth W. (1980), The Unexpected Minority, New York, Harcourt Brace Jovanivich.

Gobineau J.A. (1856), The Moral and Intellectual Diversity of Races, with Particular Reference to Their Respective Influence in the Civil and Political History of Mankind, Philadelphia, PA, Lippincott.

Goffman E.(2005), Piętno. O zranionej tożsamości, Gdańsk, GWP.

Groce N. (1985), Everyone Here Speaks Sign Language: Heredity Deafness on Martha Vineyard, Cambridge, Harvard University Press.

Heathertorn T., Kleck R., Hebl M., Hull J. (2008), Społeczna psychologia piętna, Warszawa, PWN.

Hunt P. (1966), Sigma: The Experience of Disability, London, Geoffrey Chapmen.

Hurst R. (2000), To revise or not to revice, "Disability and Society", nr 15 (7).

Illich I. (1977), Limits to Medicine. Medical Nemezis,: The Expropriation of Health, Penguin, Harmondsworth.

Ingleby D. (1983), Mental health and social order, (w:) S. Cohen, A. Scull (red.), Social control and State, Blackwell, Oxford.

Jewson N. (1976), The disappearance of the sick man from medical cosmology 1770-1870, "Sociology", nr 10.

Kapuściński R. (2006), Ten Inny, Kraków, Znak.

Kristeva J. (1991), Strangers to ourselves, tłum. L. S. Roudiez, New York, Columbia University Press.

Katz I. (1981), Stigma. A social-psychological perspective, Erlbaum, Hillsdale.

Kofta M., Szustrowa T. (red.) (2001), Złudzenia, które pozwalaja żyć, Warszawa, PWN.

Korniszowski L. (2003), Dzieci z wadami wrodzonymi, Warszawa, PZWL.

Lévinas E. (2002), Inaczej niż być lub ponad istota, tłum. P Mrówczyński, Warszawa, Aletheia.

Magala S. (1980), Simmel, Warszawa, Państwowe Wydawnictwo „Wiedza Powszechna”.

Mead M. (1978), Tożsamość i kultura. Studium dystansu międzypokoleniowego, Warszawa, PWN.

Melosik Z. (1996), Tożsamość, ciało i władza, Poznań - Toruń, Edytor.

Modrzewski J. (2004), Socjalizacja i uczestnictwo społeczne. Studium socjopedagogiczne, Poznań, Wydawnictwo Naukowe UAM.

Müller H. (2005), Lis już wtedy był myśliwym, tłum. A. Rosenau, Wołowiec, Wydawnictwo Czarne.

Pelling M. (1998), The Common Lot: Sickness, Medical Occupations and the Urban Poor in Early Modern England, London, Longman. 
Perlman J.L., Routh D.K. (1980), Stigmatizating effects of a child's wheelchair in successive and stimultanneuos interactions, "Journal of Pediatric Psychology", nr 5.

Proust M. (1969), W poszukiwaniu straconego czasu, Warszawa, PIW.

Pyszczyński T., Solomon S. (1991), A terror managamnet theory of social behavior: The psychological functions of self-esteem and cultural worldviews, (w:) M.P. Zanna (red.), Advances in experimental social psychology, San Diego CA, Academic Press. Ricoeur P. (1991), Podług nadziei, Warszawa, Instytut Wydawniczy PAX.

Ricoeur P. (1995), Pamięć - zapomnienie - historia, (w:) K. Michalski (red.), Tożsamość w czasach zmiany, Warszawa, Fundacja im. Stefana Batorego.

Ryan J., Thomas F. (1980), The Politics of Mental Handicap, Penguin, Harmondsworth.

Safilios-Rothschild C. (1970), The Sociology and Social Psychology of Disability and rehabilitation, New York, Random House.

Seymur W. (1998), Remaking of the body, Londyn, Allen \& Unwin.

Simmel G. (2006), Most i drzwi. Wybór esejów, tłum. M. Łukasiewicz, Warszawa, Oficyna Naukowa.

Snyder S. L., Mitchell D. T. (2001), Re-engaging the body: disability studies and the resistance to embodiement, "Public Culture", nr 13.

Stiker H. J. (1999), A History of Disability, University of Michigan Press.

Stone E. (1999), Disability and development in the majority world, Disability and Development, London, Disability Press.

Stradford B. (1993), Zespół Downa, przeszłość, teraźniejszość i przyszłość, Warszawa, PZWL.

Sumner G. (1995), Naturalne sposoby postępowania w gromadzie, Warszawa, PWN.

Sztompka P., Bogunia-Borowska M. (2008), Socjologia codzienności, Kraków, Wydawnictwo „Znak”.

Ternon i Hellman (1984), Eksterminacja chorych psychicznie w III rzeszy, Warszawa, PZWL.

Young I. M. (1997), Unruly categories:a critique of Lancy Frasier' dual systems theory, "New Left Review", nr 222.

Waldenfeld B., (2002), Topografia obcego, tłum. J. Sidorek, Warszawa, Oficyna Naukowa.

Vigarello G. (1996), Czystość i brud. Higiena ciała od średniowiecza do XX wieku, tłum. B. Szwarcman-Czarnota, Warszawa, WAB.

Wintzer M. A. (1993), The History of Special Education: From Isolation to Integration, Washington, Gallaudet University Press.

Wiśniakowska L. (red.), (2005), Słownik wyrazów obcych, Warszawa, PWN.

Zdanowicz-Cyganek U. (2010), Kategorie inna - obca - wykluczona we współczesnej poezji kobiecej, promotor - dr hab. S. Szymutko, prof. UŚ, Katowice, niepublikowana praca doktorska.

Zola I. K. (1993), Depiction of disability - metaphor, message and medium in the media, a research and political agenda, "Social Science Journal", nr 22. 
SUMMARY

\section{The evolution of disability in Western culture - perspective of anthropology}

Anthropology is a field broadly understood as a description of ubiquitous human existence as far as homo sapiens emerged from community of human being until present-day society.

Anthropology provides description of mechanics of integration of societies or how they distance themselves from certain group and individuals. It describes permanence and changes of culture order. According to Mary Douglas's anthropological resolving I analyse - in perspective of anthropology - evolution of social attitudes in to people with disabilities. Basical questions of my article are - „who, why, how, what" normal people thinks about persons wiht disfunctions. I present specific conceptualisation of disability's causes, ways of a treatment people with features of otherness in traditinal era and in postmodernism. I say - they give us something inducing to thinking about another face of humanity.

\section{Keywords:}

disability, evolution, Western culture, social attitudes, antropological perspective 